\title{
NAMIK KEMAL'İN MEKTUPLARINDAN YANSIYAN KIBRIS YAŞAMI
}

\author{
Bedri AYDOĞAN ${ }^{1}$
}

\begin{tabular}{|c|c|}
\hline Makale & Bilgisi \\
\hline $\begin{array}{l}\text { Kavramsal } \\
\text { DOI: } 10.3\end{array}$ & $\begin{array}{l}\text { Makale } \\
\text { 379/cusosbil.848537 }\end{array}$ \\
\hline Makale Ge & cmissi: \\
\hline Geliş & 28.12 .2020 \\
\hline Düzeltme & 15.02 .2021 \\
\hline Kabul & 16.03.2021 \\
\hline Anahtar Ke & limeler: \\
\hline Namık Ken & \\
\hline Kıbrls, & \\
\hline Sürgün, & \\
\hline Mektup. & \\
\hline
\end{tabular}

\section{ÖZ}

Tanzimatla birlikte Batıya açılan Türk edebiyatının önemli sanatçılarından olan Namık Kemal, Vatan yahut Silistre oyununun sahnelenmesinden sonra halkın çoşkuya kapılması ve gösterilerde bulunması sonucu kalebent olarak Kıbrıs'a sürülmüș ve orada 38 ay kalmıştır. Namık Kemal, edebî eserlerinin çoğunu bu sürgünlük sırasında yazmış ve yayımlamıştır. Namık Kemal'in sürgünlük yaşamı en geniş biçimde Magosa mektuplarına yansımıștır. Gündelik yaşamı, yakınmaları, çektiği sıkıntılar, Kıbrıs yöneticileri ile olan ilişkileri, Kıbrıslı sanat çevreleriyle görüşmeleri, diğer edebiyatçılarla kurduğu her türlü iletişim, ülkesi ve kendisiyle ilgili siyasal gelişmeler, özel yaşamı, ailesi ile ilişkileri ve bunun dışında daha pek çok konu mektuplara yansımış, Namık Kemal'le ilgili merak edilen hususlar mektuplarda yer almıştır. Bu yazıda Namık Kemal'in Kıbrıs'taki yaşamı ve yukarıda saydığımız konular, bașta Fevziye Abdullah Tansel'in hazırladığı Namık Kemal'in Mektupları'na ve diğer kaynaklara dayanılarak değerlendirilecektir.

\section{CYPRUS LIFE REFLECTED BY NAMIK KEMAL'S LETTERS}

\begin{tabular}{l} 
Article Info \\
\hline Conceptual Article \\
DOI: $10.35379 /$ cusosbil.848537 \\
\hline Article History: \\
Received 28.12.2020 \\
Revised $\quad 15.02 .2021$ \\
Accepted 16.03 .2021 \\
\hline Keywords: \\
Namık Kemal, \\
Cyprus, \\
Exile, \\
Letter. \\
\hline
\end{tabular}
\begin{abstract}
Namık Kemal, one of the important artists of Turkish literature that opened to the West with the Tanzimat, was exiled to Cyprus as an imprisoned in the castle after the staging of the play Vatan Yahut Silistre, and as a result of the enthusiasm of the public and the show, and stayed there for 38 months. Namık Kemal wrote and published most of his literary works during this exile. Namık Kemal's life in exile is most widely reflected in the Magosa letters. His daily life, his complaints, his troubles, his relations with the Cypriot administrators, his meetings with Cypriot art circles, all kinds of communication he had established with other literary figures, political developments about his country and himself, his private life, his relations with his family and many other issues were reflected in the letters, the curious matters about Namık Kemal were included in the letters. In this article, the life of Namık Kemal in Cyprus and the issues we have listed above will be evaluated on the basis of Namık Kemal's letters prepared by Fevziye Abdullah Tansel and other sources.
\end{abstract}

\footnotetext{
${ }^{1}$ Dr. Öğr. Üyesi, Çukurova Üniversitesi, Fen-Edebiyat Fakültesi, baydogan@cu.edu.tr, ORCiD: 0000-0002-5450-551X. Alıntılamak için/Cite as: Aydoğan, B. (2021), Namık Kemal'in Mektuplarından Yansıyan Kıbrıs Yaşamı, Çukurova Üniversitesi Sosyal Bilimler Enstitüsü Dergisi, 30 (1), 157-165.
} 
Çukurova Üniversitesi Sosyal Bilimler Enstitüsü Dergisi, Cilt 30, Sayı 1, 2021, Sayfa 157-165

\section{GíRiș}

Türk edebiyatında vatan ve özgürlük şairi olarak tanınan 1840'ta Tekirdağ'da doğan, 1888'de Sakız'da ölen Namık Kemal 48 yıllık yaşam sürdü. Kısa sayılacak ömrünü gurbet, sürgün ve hapiste geçirdi. Bu durumu bir mektubunda "Ben anamdan doğdum doğalı gezmeye alıştım" diyerek ifade eden Namık Kemal'in (Kuntay, 1956, s. 674) çocukluğunda ve gençliğinde dedesi Abdüllatif Paşa ile birlikte Afyon, Kars, Sofya gibi yurdun çeşitli yerlerinde dolaştıktan sonra (Akün, 1988, s. 55-56) 1857'de İstanbul'a babasının yanına geldi ve memuriyete başladı. Çeşitli görevler yaptığı konusunda değişik görüşler olan Namık Kemal (Akün, 1988, s. 57 ) memuriyetinin çoğunu Tercüme Odasında geçirdi. Ebuzziya Tevfik'e göre 1857'de 17 yaşındayken göreve başlayan Namık Kemal, 1867 yılında Erzurum Vali muavinliğine atandı. Bu göreve başlamayan Namık Kemal gurbete çıkt. Paris ve Londra'da Hürriyet gazetesinde muhalefetini sürdürdü. 6 Eylül 1870'te Hürriyet'ten ayrılan Namık Kemal yazı yazmamak koşuluyla affedildi ve 24 Kasım 1870'te İstanbul'a döndü. Ali Paşa'nın ölümüyle yeniden gazeteciliğe dönen Kemal, İbret'in başyazarı oldu. 26 Eylül'de Gelibolu mutasarrıflığına başlayan Kemal, azledildiği için 25 Aralıkta İstanbul'a döndü ve cezası erken bitirilen İbret'te yazmaya başladı. 1 Nisan 1873'te Vatan Yahut Silistre oyununun Gedikpaşa Tiyatrosunda sergilenmesi üzerine halkın coşkuya kapılması sebep sayılarak dört arkadaşıyla birlikte tutuklandı ve kalebent olarak Magosa'ya gönderildi (Aydoğan, 2003, s. 17-19). 6 Nisan'da tutuklanan Kemal ve arkadaşları 9 Nisan'da İstanbul'dan ayrılmak üzere vapura bindirildiler. Çanakkale'de başka bir karakol vapuruna aktarılıp üç gün bekletildikten sonra özel bir vapur onları sürgün yerlerine dağıtmaya başladı. Önce Rodos'ta Ahmet Mithat ve Ebuzziya Tevfik indirildiler. Diğerleri geceyi vapurda Rodos'ta geçirdiler. Ertesi gün Kıbrıs açıklarında sandala aktarılan Namık Kemal, adaya çıkarıldı ve 38 ay sürecek Kıbrıs yaşamına ilk adımı attı (Aydoğan, 2003, s. 19).

\section{Adaya Çıkış Lefkoşa Yerine Magosa'ya Gidiş}

Namık Kemal'e başta Lefkoşa'ya gideceği söylenmiştir. Sonradan ceza yerinde bir değişiklik yapıldığından Magosa'ya götürülür. Kemal Magosa'nın Lefkoşa'ya göre daha olumsuz bir sürgün yeri olduğunu düşünmektedir. Namık Kemal bu düşüncesini bir mektubunda Magosa ve Akka için “Magosa gibi (Akün’e göre "gibi” mektubun orijinalinde yok), Akkâ gibi ufûnet ve kerâhetlerine nazaran rûy-i arzın kurtlaşmış iki çibanı denilmeğe lâyık olan yerler" nitelemesini yaparak ortaya koyar (Tansel, 1967, s. 237). Aynı mektupta Magosa hakkında başka pek çok bilgiye daha yer verir. Bu bilgiler Magosa'yı her yönüyle tanıtan bilgilerdir. Bir kısmı Magosa'nın coğrafyasına ve iklimine yöneliktir. Namık Kemal'in üç yıl yaşadığı yeri ve oraya ilişkin duygularını anlatması açısından bu mektup son derece önemlidir.

İlk olarak "Pencereden bakıp da sahrâlar dolu harâbelerini, dağlar parçalanmışçasına taş yığınlarını gördükçe, Sûr-ı İsrâfil çalınmış, fakat ben işitmemişim zannediyorum" (Tansel, 1967, s. 238) diyerek Magosa'nın doğal yapısından söz eder. Kaldığı kaledeki evleri mezara, içindeki insanları ölüye, giysilerini de yırtık kefene benzetir. Olumsuz hava ve iklim koşulları nedeniyle Kıbrıs halkını gerçek bir mücahit olarak görür: "Çünki havasından dört tarafa eslâha-i cedîde sadâsı kadar mütenevvi' ilel-i mühlike dağlliyor ve hattâ içlerinden en hafifi olan ısıtma bile insanı, şişhâne (şeşhâne) kurşunu kadar sür'atle öldürüyor.” (Tansel, 1967, s. 238)

Namık Kemal, bu olumsuz iklim ve doğa koşullarına ek olarak, her şeyin Londra'dan bile pahalı olduğu tespitini yapıp, halkın yoksulluğunu, bu yüzden arpa ekmeğini bile zor bulduklarını anlatır. Suyu için de şu belirlemelerde bulunur:

Kuyulardan çektirilip de içtiğimiz sudaki şâb ile küherçileyi bir yere toplasalar, Mısır Çarşısı'nı değil, Kâhire'nin barut-hâneleri ile Tanta mevlidi'nin şâhid-i pazar olan çingânelerini, asırlarca idare eder. Evvel ağızdaki acılı̆̆ı def için rakı üzerine su içiyorduk; şimdi bi’l'akis su üzerine rakı içiyoruz. (Tansel, 1967, s. 239)

Namık Kemal, havası ve suyundan sonra sözü Magosa'nın böcek, sürüngen ve kuşlarına getirir:

Buranın nevâdirinden olmak üzere devlet-i dünya kadar müzeyyen, bîvefâ eviddâ kadar zehr-âkin yılanları var. Hele kertenkelelerini Peder Paşa hazretlerinin şerîk-i mihnetleri olan Emin Beyefendi timsah zannetmiş; fakat bendeniz cesâmetlerine, zarâfetlerine, u'cûbe-i klyafetlerine, eğilip bükülmekte ve insanın yüzüne baktıkça ağızlarını kulaklarına değdirmekte hâletlerine, bir taraftan koğuldukça diğer taraftan baş göstermekte mahâretlerine nazaren, dünyada dört ayaklı birçok Lâstik Sa '̂̀d peydâ olmuş klyâs ediyorum.

Bundan başka, eâlimizin haremlerindeki Hadım Ağaları'ndan, selâmlıklarındaki musîbet dellallarından ziyâde kargası, baykuşu var." (Tansel, 1967, s. 239)

Namık Kemal, 


$$
\begin{aligned}
& \text { Fâresi zümre-i küttâb gibi nâ- mahdîd (nâ-ma'dûd) } \\
& \text { Pîresî leşker-i küffâr gibi bî-pâyân (Tansel, 1967, s. 239) }
\end{aligned}
$$

beytiyle de Magosa'nın faresi ve piresinin sınırsız olduğunu belirtir. Bunlara ek olarak sivrisinek ve tatarcıkların da insanın hatırını hemencecik sorduğunu söyledikten sonra bitki örtüsüne geçer. Bu bakımdan da görüntü olumsuzdur. Hanzel (portakal büyüklüğündeki meyvesi acı bir bitki) ve mugeylanlarıyla (deve dikeni) çölle yarışır özellikte bir bitki örtüsüne sahiptir. Bu coğrafya ve toprak yapısından da daha iyi, daha gönül açıcı bir görüntü beklemek olası değildir.

Kemal, son olarak Ada'nın madenlerden yana nasipsiz olduğu üzerinde durur. Kayda değer bir maden yoktur, ama başta da söylediği gibi bolca taş ve kaya vardır. Bunların en ufak parçası insana "işkence" etmekte bir "cellat" ayarındadır. Toprağının İran çöllerinden Magosa'ya atıldığını düşünen Kemal, "göz çıkartmakta kızgın milden geri kalmıyor" diyerek kendince en temel özelliğini belirler.

Namık Kemal'in ilk izlenimlerinin ve bu yolda aktardıklarının hiç de iç açıcı olmadığı görülüyor. Onun verdiği bu bilgiler, doğal çevre, iklim, hava ve su açılarından Magosa'nın yaşanacak bir yer olmadığını ortaya koyuyor.

Namık Kemal mektuplarında kaledeki yaşayışa ve duruma dikkati çeker. Bu noktada da yaşadığı, gördüğü, tanık olduğu olay ve durumlar iç açıcı değildir. Namık Kemal kaleye geldiği ilk gün mezar gibi bir yere konulur. Kaleyi de bir bütün olarak mezara benzetir zaten. Kaledeki evler için de mezar nitelemesinde bulunur. Orada yaşayanları ise yırtık kefenleriyle mezara girmiş ölülere benzetir.

Namık Kemal mektuplarında kaleye gelişini de anlatır. Bir süvari yüzbaşısı, dört süvari ve iki topçu erinden oluşan yedi kişilik bir gözetim birimi kendisine eşlik eder. Bu büyük güvenlik önlemleri yolda kaçmaması için alınmıştır. Konulduğu yerin özelliğini “Buraya geldim; heman o gece, asker için yapılmış, tamam mezar kadar bir yere tıktılar.” (Tansel, 1967, s. 247) cümlesinden öğreniyoruz. Kapının önüne iki de nöbetçi konulmuştur. Kemal ilk gecesini geçirdiği "mezar"1, kendi durumu ve duyguları hakkında kısa bir bilgi verir: "Altım taş olarak, üzerinde bir hasır ile, bir asker fanilâsı var idi. Sonradan fanila inceliğinde bir de şilte getirdiler. Setremi yastık, paltomu yorgan ettim; fâsılasızca dokuz saat rahat rahat uyudum;" (Tansel, 1967, s. 247)

Odasına ilk geldiği zaman Namık Kemal durumunu ve yaşadıklarını değerlendirmiş, duygularını mektuplarına, bu yolla yakınlarına, sevenlerine aktarmıştır. Çektiği sıkıntılar onun inandığı yoldaki gücünü ve kararlılığını pekiştirmiş, kendisine olan güvenini artırmıştır. Yaşadıkları, yürüdüğü yola ve inandıklarına ne kadar sadık kaldığını denediği bir mihenk taşı olmuştur. Başına gelenler nedeniyle hiçbir üzüntü ve pişmanlık duymamaktadır. Yürüdüğü yolda karşısına çıkacak zorlukları başından beri bilmekte ya da en azından tahmin edebilmektedir. İlk gece hiç uyanmadan dokuz saat uyuması, üzüntü ve pişmanlık duymayışının ve endişesizliğinin bir göstergesidir. Boru sesleri, askerlerin hareketliliği bile Namık Kemal'i uyandırmamış, hatta öldüğü kuşkusu yaratmıştır. Bunun da nedeni daha önce burada sürgün olan Emin Bey’in tepkisidir.

Namık Kemal bir başka mektubunda daha odasından söz eder. Merdiven altındaki karanlık odayı bu mektubunda da mezara benzetir. Ona göre Magosa bütünüyle harabe gibi bir yerdir. Kale topçuları için yapılmış olan bina oturulmaya uygun değildir. Namık Kemal burada bir müddet oturmak durumunda kalmıştır.

Mahbesimin, 'kışlanın iki dirseği arasında yapılmış bir penceresi, bir de eğilmeden girilmesi muhâl bir kapusu var idi. İçine girdim. Kenardaki taş dirseği üzerine yorgana benzer bir şilte serdiler; bir tarafina da çârşaf inceliğinde bir yorgan, bir tarafina şilte kalınlığında bir yastık koydular. '; Ben ise o câme-ha'b-l huzur üzerine uzandım. Baktım ki odanın tûlü boyuma göre yapılmış, her taraf toprak. Bir cihette iğne deliği kadar menfez yok. Âdetâ yeryüzünde bir lahd içindeyim. (Tansel, 1967, s. 254)

Genel olarak Magosa, kale ve kaldığı ev çok uygunsuz da olsa, Namık Kemal bulunduğu yere uyum göstermeye çalışır, moralini yüksek tutar. Öte yandan vatan, özgürlük yolunun çeşitli engellerle dolu olduğunu bilir. Bu yola girenlerin böyle sıkıntıları kabul etmeleri gerektiğinin farkındadır. Bununla birlikte zaman zaman evinin değiştirilmesi için girişimlerde bulunur. Veys Paşa zamanında İstanbul'a bu dileğini iletmiştir. Şirvanizade Rüştü Paşa sadrazam olunca Namık Kemal, onun oğlu Hakkı Bey’in kendisine yakınlık göstermesine bakarak ümitlenir. Ev konusunda bir cevap beklemektedir. Hakkı Bey’e yazdı̆̆1 mektubunda şunları söyler:

Evvelâ arkadaşlarım zarûrette kalmamak; sâniyen bir eve çıkıp oturabilmek. Bu ikinci mürâcaat zaten kararlaşmış olduğunu, şu arîzamı takdim eden zât, zâten tebşîr etmiş idi. Postayı bekliyorum, eğer kararlaştı ise febihâ! Kararlaşmadı ise, himmet, memlekete sarf buyurulmalıdır; çünki, bulunduğum yerin rutûbet ve bürûdetinden vücutce fevka'l-gâye muztaribim. Şu iş kararlaşınca, bayağı hayatım kurtarılmış olur. (Tansel, 1967, s. 281 ) 
Görüldüğü gibi Namık Kemal kaldığı yerden şikâyetçidir. Soğuk, rutubet gibi olumsuz koşullar onu sıkıntıya sokmuştur. Sağlığı açısından kaygılıdır. Veys Paşa ile Rüştü Paşa’ya bir dilekçe göndermiştir. Oradaki üslubunun biraz sert olduğunu düşündüğü için mazur görülmesini ister. Bu ev işinin kendisi için ne kadar önemli olduğu "Hele şu eve oturmak hâsıl olur ise, şimdilik nefsimce en büyük bahtlyarlıklardan olur." (Tansel, 1967, s. 281) demesi gösteriyor.

Namık Kemal'in Magosa hakkında aktardıkları genellikle olumsuz izlenimlerdi. Magosa hakkında olumlu sözler yazdığı da olmuştur. Kızı Feride’ye yazdığı bir mektubunda bunu görüyoruz:

Ben burada o kadar rahattayım ki ta'rif edemem. Her akşam denize giriyorum; Magosa'da bir koca liman var; beyaz kum içinde.. Insan, Unkapanı'ndan Galata'ya kadar bir (yer) gidiyor, yine deniz, boğazına kadar çıkmıyor.. Hele bilsen, o beyaz kum, suyun içinde ne güzel görünüyor.. Tıpkı tıpkısına, sizin Istanbul hanımefendilerinin yaşmak altında parlayan çehreleri gibi.. (Tansel, 1967, s. 288)

İnsanın psikolojik durumu ile olaylara bakışı arasında bir koşutluk olması doğaldır. Kemal kızından mektup aldığı için sevinmiştir. Üç yeni oyun yazdığı için de mutludur. Bu çevreye bakışını değiştiriyor. Daha önce Magosa'nın olumsuzluklarını anlatmış ve yakınmıştı. En çok üzerinde durduğu hususlar ise iklim ve doğal çevreye ait olumsuzluklard1.

İlk günlerdeki alışma devresinden sonra Namık Kemal'in Kıbrıs'taki yaşamı biraz daha olağanlık ve düzenlilik kazanmıştır. Mektuplar aracılığıyla ailesi ve dostlarıyla iletişim kurmaktadır. En büyük sıkıntısı gazetelere ulaşmadaki güçlüktür. Bu nedenle siyasi ve edebî havayı koklayamamaktadır. Buna karşılık istediği kadar verimli olmasa da edebî çalışmalarını sürdürmektedir.

İstanbul'dan ve başka yerlerden çeşitli gereksinimlerini karşılamaktadır. İçki de bunlar arasında önemli bir yer tutar. Mektubunda bir cins Kıbrıs mantarı olan Kafkarit 1smarladıklarını yazıyor. Şarabı da Limasol'a sipariş etmişlerdir. Bütün bunlar Ada’ya uyum sağladığını gösteriyor. Ancak haşerat konusundaki yakınmaları sürmektedir.

Kıbrıs'ta mutasarrıf olan Veys Paşa, Namık Kemal'in ailesi ile haberleşmesinde kolaylık sağlamıştır. İlk olarak İstanbul'dan gelen uşağıyla, kaymakam ve bir subay gözetiminde konuşmuş, uşağa bir de açık mektup vermiştir. Özel bir görüşme olanağı tanınmasa da bir adım atılmıştır. Bu adım dolayısıyla Veys Paşa'ya teşekkür için bir mektup yazar ve çektiği sıkıntılar nedeniyle üzülmediğini, İstanbul'a dönmek gibi bir arzu duymadığını belirtir. Veys Paşa'dan özellikle gazete ister. Okunmuş gazetelere bile razıdır. Magosa'ya vapur on beş günde bir uğradığından Lefkoşa'dan gelen okunmuş gazeteler daha taze kalmaktadır.

Veys Paşa'nın oğlu Zeynelabidin Reşid'in Kıbrıs'a geleceğini Veys Paşa'nın muavini Mustafa Efendi'den öğrenen Kemal çok sevinir. Zeynelabidin Reşid'e yazdığı mektupta kendisi gelemezse Reşid'in Magosa'ya gelmesini istediğini söylüyor. Bu cümleden Kemal'in kaleden ayrılabildiği anlamı çıkabilir. Ancak Kemal'in kaleden çıktığına dair pekiştirici bir bilgiye rastlayamadım. Sadece kızına yazdığı bir mektupta denize girdiğini söylemişti. Zeynelabidin Reşid'in İstanbul'dan bir şey isteyip istemediği sorusuna ise "Bir şey istemekliğimi teklif buyurmuşsunuz. Bir şeye muhtâcım; o da mevadd-ı havâdis.. Mükemmel, mufassal isterim.." diye yanıt veriyor (Tansel, 1967, s. 266). Kemal'i en çok yalnızlık ve dostlarından doyurucu haber alamaması üzüp yıpratmaktadır. Beklenti ve istekleri maddi değil manevidir.

Bir süre sonra Veys Paşa Kıbrıs'tan ayrılır. Bu ayrılık bazı sıkıntıları da beraberinde getirdiğinden Kemal'i çok üzer. Kendisine hayat veren gazeteler gelmez olmuştur. "Veys Paşanın infisâlinden beri, gazete görmekten bütün bütün mahrum gibiyim” (Tansel, 1967, s. 292) sözleri bu konudaki sıkıntısını ortaya koyuyor. Posta gelince oradan çıkacak gazeteler için müteşekkir olacağını belirtiyor. Yeni atanan Nazif Paşa'ya yazdığı kutlama mektubunda Kemal, bu sıkıntılarını dile getirir. Ayrıca Veys Paşa'nın kendisiyle konuşmaktan, ilişki kurmaktan çekinmediğini söyler. Nazif Paşa ile görüşmekten memnunluk duyacaktır. Kemal, Nazif Paşa'yı görmekle İstanbul'a gitmiş kadar sevineceğini de söyler (Tansel, 1967, s. 292). Tabii bu ilişskide Nazif Paşa'nın tutumu belirleyici olacaktır. Suçu olmasa da neticede Kemal bir mahkûmdur.

Namık Kemal'in Magosa'daki yaşamı genellikle sıkıntılı geçmiştir. Kemal büyük bir maddi sorunla karşılaşmaz. İstanbul'dan Veliaht V. Murat tarafından destek almakta, babası kendisine birçok konuda olduğu gibi maddi konularda da yardımcı olmaktadır. Sürgündeki diğer arkadaşları maddi açıdan daha çok sıkıntı çekerler. En çok sıkıntı çekenler Akka'da olanlardır. Bir mektuplarında eti unuttuklarını, et yerine işkembeden başka bir yiyecek görmediklerini yazarlar. Kemal onlar için üzülür ve elinden geldiğince yardımda bulunur. Rodos'takiler ile Kemal, Nuri ve İsmail Hakkı Beylere paraca yardım ederler. Buna ek olarak Kemal, Tasvir-i Efkâr matbaasını satıp parasını Akka’ya göndermek ister, ama bu gerçekleşmez. Belki de buna gerek kalmamıştır. Namık Kemal'in matbaayı satıp arkadaşlarına yardım etme düşüncesi, onların birbirlerine ne kadar sıkı ve candan bir sevgiyle bağlandıklarını göstermektedir. 
Çukurova Üniversitesi Sosyal Bilimler Enstitüsü Dergisi, Cilt 30, Sayı 1, 2021, Sayfa 157-165

Namık Kemal Magosa'ya geldikten on dört ay sonra Hüsnü Paşa’ya yazdığı bir mektupta sorunlarının bitmediğini, çok ıstırap çektiğini anlatır. Kıbrıs mutasarrıflarının iyi tutumu karşısında geçici olarak rahat ve huzura kavuşur. Ancak bu rahatlık kişilere bağlıdır ve sürekli olmaz. Hâlâ kaçabileceği endişesi ile aşırı baskı altında tutulmaktadır. Vaktiyle Kıbrıs'ta sürgün olarak bulunan Hüsnü Paşa şimdi Zaptiye Müşiri olmuştur. Bu yeni görevini kutlamak için Hüsnü Paşa'ya yazdığı mektupta Kemal sıkıntılarının ne derece arttığını ve ruh durumunu ortaya koyuyor:

Kulunuzun fermanında kal'ebend olduğum ve kal'ebendlik nizâmına tevfikan muâmele görmekliğim musarrah iken, burada bulunan kâtillerden ve hattâ Bâbîler'den şeni' tutularak, tevkîf-i askerî tahtında bulunuyorum. Nizâmât-ı askerîye'nin şiddeti ve kışlanın rutûbeti, havanın zâten der-kâr olan vahâmetine munzam olarak, arada sırada şedît şedît keyifsizliklere uğramaktayım. Allâh bilir ki, yine kalben münkesir değilim; fakat vücûdüm tahammül (İki kelime bozulmuştur.)

Vaktiyle ordular battran zâtlar buraya nefyedilmiş, yine tevkîf-i askerî (iki kelime bozulmuştur), böyle muhâkemesizce bir yere gönderilen adamın, bu derece tazyîk olunmasına ne İslâmiyet, ne insâniyet, ne hükûmet kâ'il olur zannederim.

Ĕger firârımdan ihtirâz buyuruluyor ise, onu, iki delil ile te'min edebilirim. Evvelâ kulunuz öyle bir şenı̂'ayı irtikâp edip de, şerîk-i felâketim olan dört arkadaşımı belâ içinde iken, belâ-ender-belâ hâline düşürecek kadar denî olmadiğımı, Efendilerimiz de tasdik buyururlar sanırım. Sâniyen ondört aydan beri bu hâl içinde iken, muhâfazama me'mur olanlarca öyle bir işe kalkışabileceğimden zerre kadar şüphe verecek bir harekette dahi bulunmadım. Firar niyetinde bulunmuş olsa idim, böyle bir zindân-ı belâ içinde ondört ay bekleyecek kadar ahmak veya korkak olmadığımı da, âsâr ü ef'âl-i kemterânem gösterebilir. Bu kadar tafsîlâtın neticesi olan hulâsa-i murâd-ı kemterânem, sair arkadaşlarım gibi (İki kelime bozulmuştur.) ve kal'ebendlik nizâmı ne ise ona göre muâmele görmekliğim husûsunda, emr-i âlî-i müşîrânelerini istid'âdan ibârettir.

İstid'â-yı kemterânem nizâm ü insâfa mugâyir ise, tervic buyurulmasın. I'dâm ile mahkûm isem, kulunuzca böyle rutûbetçe tesmîm ve habs ile tazyik olunarak ölmekten, kurşuna dizilmek evlâdır. (Tansel, 1967, s. 298-9)

İdarecilerin tutumuna bağlı olarak zaman zaman rahat günler de geçiren Kemal'in bu mektubu çok sıkıntıda olduğunu gösteriyor. Neredeyse isyan noktasına gelmiştir. Bir kez daha ağır koşullardaki hapislikten şikâyet eder. Rutubet onu yavaş yavaş zehirlemektedir. Sinek ve sıtma en çok uğradığı belalar arasındadır. Sık sık hastalanıp yatağa düşer. Bu durumda edebî çalışmaları sekteye uğrar. Bazen doktor yazı yazmasına bile izin vermez. Hatta bir keresinde hastalıktan ve yitirdiği iki arkadaşının üzüntüsünden kör olma tehlikesiyle karşılaşır.

Magosa, Namık Kemal için pek çok yönden bir çöl kuraklığındadır. Gazete bulmakta güçlük çeker. İstediği kitaplara ulaşması zaman alır. Oysa eserlerini yazmak için kitaba gereksinimi vardır. Bunu sağlamak için arkadaşlarına başvurur, İstanbul'a, Avrupa'ya sipariş verir. Magosa'da onun en büyük tesellisi kitaplar ve dostlarından aldığı mektuplardır. "Kâğıdımın kısalı̆̆ına bakmayınız; cevap-nâmelerinizi uzun isterim; çünkü zannıma göre burada aldı̆̆ımız mektuplarla konuşacağız.” (Tansel, 1967, s. 319) yazması en önemli iletişim aracının mektuplar olduğunu açıkça ortaya koyuyor. Recaizade Mahmut Ekrem'in mektubu için üç sahifecik demesi çok uzun mektuplar beklediğinin, buna gereksinim duyduğunun bir ifadesidir (Tansel, 1967, s. 344). Kızından mektup aldığında sevincini çok açık ve samimi olarak gösterir. Kızına yazdığı otuz altı mektubun hepsinde bu sevinç görülmektedir.

Namık Kemal'in suçsuz yere Magosa'da otuz sekiz ay geçirmesi fiziksel ve ruhsal yönden kendisini yıpratmıştır. Ancak ruhsal yönden direnç göstermeye çalışır. Bu hem karakterinin güçlülüğünden hem de yakınları ve dostlarının kendisine olan desteğinden kaynaklanır. Ona direnç veren çok önemli bir şey de edebiyattır. Namık Kemal Magosa'da edebiyatla sıkıntılarını hafifletmiştir. Edebiyat aracılığıyla düşüncelerini halkla paylaşmış ve onlara bu araçla yol gösterici olmaya çalışmıştır. Magosa sürgünlüğünün Kemal'e en büyük katkısı edebiyatla uğraşma olanağı sunması olmuştur. Gerçekten de Kemal edebî ürünlerinin çoğunu bu otuz sekiz ay içinde verir.

\section{Sürgün Arkadaşlarıyla Mektuplașmaları ve İlișkileri}

Namık Kemal sürgüne birlikte çıktıkları arkadaşlarıyla sık olmamakla birlikte mektuplaşır. Onların sürgünlük yaşamından haberdar olur, kendisinin Kıbrıs yaşamından kesitler sunar. Mektuplaşmaların ilki Kıbrıs'a 
gitmeden, Rodos'ta vapurda kaldıkları gece olur. Namık Kemal gurubu anlatır, uyumazsa tuluu da anlatacağını söyler. Uyur da tuluu göremezse orada kalan Mithat ve Tevfik'in anlatmalarını ister. İkinci mektubu Kıbrıs'a çıkınca Nuri Bey’e yazarak kendisinin Lefkoşa değil, Magosa'ya doğru götürüldüğünü bildirir.

Bundan sonra Ebuzziya Tevfik'e ilk mektubunu sürgünlüğün 18. ayında 1874 Eylül'ünde yazar (Tansel, 1967, s. 306-7). Kardeşim diye mektubu bitirmediğinden Ebuzziya Tevfik gücenmiştir. Kemal, duygusal mektubunda onu gücendirmeyi aklından bile geçirmediğini, böyle düşünmenin kendisi için bir ceza olduğunu söyler. Ebuzziya Tevfik iletişimi kesme yolunda hakkı olduğunu söylemesine üzülür. Neyse ki Ebuzziya Tevfik'ten hemen bir mektup daha gelmiştir de bu Kemal'i ferahlatır. Tevfik'e sevgisini bir kez daha belirtir. Ancak güceniklik henüz tam olarak aşılmamıştır. Bir ay sonra Kemal bir mektup daha yazarak vatanın içinde bulunduğu koşullar nedeniyle de gücenikliği uzatmamak gerektiğini ve birbirlerine iletecek çok haberin olduğunu söyler (Tansel, 1967, s. 307-8)

Bir mektubunda Ebuzziya Tevfik Mâhiyât-1 Ulûm adlı bir kitap yazacağından Kemal'e söz etmiş, Kemal bununla ilgili görüşlerini yazmıştır. Namık Kemal'in görüşleri Ebuzziya Tevfik tarafından bir tekdir ve tazir olarak görüldüğünden yine bir gücenikliğe yol açmıştır. Kemal bu gücenikliği gidermeye çalışır. Sözlerinde bir tekdir ve tazir olmadığını yalnızca görüşlerini belirttiğini söyler. Bu başlık Namık Kemal'e çok geniş ve kapsamlı olduğundan altını doldurmak güçtür. Böyle bir kitap yazmak, Şark ve Garp bilimlerinde on sene okumayı gerektirir.

Mâhiyât unvanlı bir eserde, ulumun mahiyetinden bahsolunur. Insan hatasinda ashab-l insafin müsamahasına mazhar olur; fakat Mâhiyât-ı Ulûm ınvanlı bir kitap meydana çıkarılınca, onun hakkını ifade etmek, hiç olmazsa bizi ulûm-ı Şarkiye ve Garbiyede on sene okutmağa tevakkuf eder. Bence ya Mevzuat veya Seyyid'in Tarifat'ı yolunda bir şey yapmalı; hatta baksan a, koca Seyyid bile Tarîfât demiş; Tarifat-ı Ulûm dememiş. . Hasılı birader biz Sokrat gibi bir hakim, Russo gibi bir edip olabiliriz; fakat İbn-i Sina gibi, Seyyid gibi, Ibn-i Kemal gibi, Humbolt gibi bir alim geçinmeğe kalkışır isek haddimizi bilmemiş ve Ahmet Mithat'lar, Ali Suaviler gibi şarlatanlara bu yolda şerik oluruz. (Tansel, 1967, s. 415)

Namık Kemal, uğraşı alanlarının edebiyat olduğunu, bu yüzden Russo kadar bir yazar olabileceklerini ancak Seyyid, Humbolt kadar bir bilgin olamayacakları gerçeğine işaret edip haddi aşmamak gerektiğini söyler. Kendini ve sınırlarını bilmeyip haddi aşmayı şarlatanlık olarak görür. Bu arada Ali Suavi ve sürgün arkadaşı Ahmet Mithat'ı ağır bir biçimde eleştirir. Sadece Mahiyat denilerek konuyu daraltmayı önerir. Böyle bir başlıkla çıkacak kitaba imzası ile katılabileceğini söyler.

Namık Kemal'in Magosa'dan mektup gönderdiği diğer kişiler Türk edebiyatında üstad namıyla tanınan Recaizade Mahmut Ekrem ile dâhi namıyla tanınan Abdulhak Hamit'tir. Namık Kemal'in ise bir unvanı yoktur. O kendini bir öğretmen olarak görür, en büyük arzusu da yeni edebiyatı savunacak, bu yolda örnekler verecek sanatçıları keşfetmek ve edebiyata kazandırmaktır. Sürgünde olduğu için bunu mektuplarıyla yapmaya çalışır. Ekrem, edebiyatın henüz başındadır ve ilk iki şiir kitabı Nağme-i Seher ve Yadigar-1 Şebab’1, çeviri olarak da Atala ile Me Pirsons'u yayımlamıştır. Ekrem'le mektuplaşmaları onu sürgünlügüunde mutlu etmekte ve Kemal'e moral vermektedir.

Biraderim Ekrem 'im Efendim,

Mektubunu aldım; teşekkür ederim. Teşekkür ederim ki o meşagil-i takatfersadan bir saat kadar bile olsun vakit bulabilmişsin de, bana üç sahifecik mektup yazmışsın. Ĕger o da gelmese idi, bayă̆ı canım sıkılacak idi; vefasız olmadı̆̆ını bilmesem, daima.... halinde bulunmazdım. (Tansel, 1967, s. 344)

Kemal bu mektupla birlikte Me Prisons'u almış ve okumuştur. Bu eserini diğer eserlerinden aşağı bulur ve eleştirir, ancak eleştirilerinin Ekrem'den çok çeviri eserin sahibine yönelik olduğunu belirtir. Bununla birlikte Ekrem'in çevirisinde de kusurlar bulur. Bunlar kafiye-perdazlığa ve zincirleme tamlamaların aşırılığına yöneliktir. Ekrem'i bir noktada daha eleştirir, o da kalemini telif eserler yerine çeviriye hasretmesidir. Namık Kemal çevirinin önemini bilse de Ekrem'den telife ağırlık vermesini bekler.

Namık Kemal daha önceki bir mektubunda Atala'yı okumuş, beğenmiş, duygulanmış ve ağlamıştır. Ağlamasının sebebi “Allah, büyüktür, vatan mukaddestir" sözünü "Vatan büyüktür, vatan mukaddestir" biçimine getirip yazma cesaretini göstermesindendir. Kemal, vatanın böyle sözleri söyleyenlerle iftihar etmesi gerektiğine inanır ve Ekrem'i övgü ve takdirle karşılar. Bununla birlikte iki noktada eleştirmekten geri durmaz. Birincisi Ekrem'in Ebuzziya Tevfik'i Ecel-i Kaza nedeniyle eleştirmesidir. Çünkü Ebuzziya Tevfik hapistedir ve kendini savunma olanağı yoktur. Bunu Ekrem'e yakıştıramaz. İkinci eleştiri noktası Atala' da gördüğü bir teknik kusurla, pek çok dil kusurudur: "Gülmüyor değil, kan ağllyor.. Iffade muvazzah değil; ben olsam gülmek şöyle dursun kan ağllyor ve yahut gülmek nerede kalır, kan ağllyor der idim. Matem kasidesi yerine, bilmem ki niçin mersiye demedin?" (Tansel, 1967, s. 286) 
Alıntıladığımız bu bir örnek dahi Kemal'in haklılığını gösterir. Kemal eleştirmekle kalmaz, düzeltmeler yapar ve isabetli önerilerde bulunur. Eleştirileri son derece dostane ve yapıcıdır.

Namık Kemal, Ekrem'e yazdığı bir başka mektupta Abdulhak Hamit hakkında bilgi ister. Çünkü Hamit'le bir kere yüz yüze gelmiş bir kere de uzaktan görmüş, ancak yazdığı eserlerin bazılarını görmüştür. Gördüğü kişinin piyeslerini beğendiği Hamit olup olmadığını merak eder. Ekrem'e onu tanımak amacıyla bazı sorular sorar:

Hamit Bey’in, Macera-yl aşk ve İçli Klz ünvanlı iki eserini gördüm. Benim tahminime göre bu Hamit Bey, Nasuhi Bey'in küçük biraderi olacak. Avrupa'ya gitmeden bir kere, Tercüme Odası'nda görmüş idim. Avdetimden sonra da bir kere sokakta gördüm. Müşahedatımdan anlayışım, şimdi ondokuz veya yirmi ve nihayet yirmibir yaşında olacak! Bu halde oyunlarl kendi yazdı ise, yani sen tashih etmedin ise (İstanbul'da senden başka o şivede adam yoktur) demek ki çocuk, hiç olmazsa bizim kadar bir edip olacak.. Oyunlarını, heyet-i umumiyesi ile kabul ettim zannetmezsin !.. Eserlerin gerek tertip ve tasvirce, pek çok muaheze götürür yerleri var; fakat teşbih ve tahayyül ve ara sıra teşrih-i vicdan cihetleri, bizim mesleki pek ziyade andırlyor. (Tansel, 1967, s. 378)

Bu alıntı Namık Kemal'in edebiyattan ve gelecek vaat eden yazarlardan ne kadar iyi anladığını gösterir. İki oyunuyla Hamit olduğunu düşündüğü kişinin yeni edebiyatın büyük bir yazarı, temsilcisi olacağını tahmin eder. Kemal, Ekrem'e şu dört soruyu yöneltir.

Hamit Bey benim bildiğim çocuk mudur?

Sinni tahmin ettiğim derecede midir?

Eserler tashihten beri midir?

Kitaplarında onun neşriyatına dair ilanlar görüyorum; daire-i ülfet ve mahremiyetinde midir?

İlk üç soruya evet cevabı verilmesi hâlinde, Kemal'e göre edebiyat dünyasına ikinci bir Ekrem gelmiş demektir. Kemal, Hamit'e her konuda öğretmenlik yapmak istediğini belirtir ve onunla yakından tanışmak için aracılık yapıp yapmayacağını sorar. Kendileri gibi düşünen ve yazan birini kardeş olarak görmekten mutlu olur.

Namık Kemal Magosa'da tanıdığı ve edebiyat açısından gelecek gördüğü başka gençleri de destekler ve edebiyat dünyasına katılmaları için İstanbul'daki dostlarından ilgi ve yardım bekler.

\section{Namık Kemal'in Ailesi ile İletișimi}

Namık Kemal, ailesi ile iletişimini kızı Feride’ye yazdığg mektuplarla gerçekleştirir. Feride’ye yazdığ mektup sayısı 36'dır. Bu sayı elde olan mektupların sayısıdır. Namık Kemal'in mektuplarının dörtte biri kadarı elimizde olduğuna göre, kızı Feride'ye daha pek çok mektup yazdığını düşünebiliriz. Mektupların çoğunda pek sevdiği ve düşkün olduğu kızından sık sık mektup yazmasını ister. Mektuplar geciktiğinde ona sitem eder, darılır ve kızı için endişelenir. Aşağıdaki 207 numaralı mektup, bu söylediklerimizi yansıttığı gibi bazen mektupların arasının açıldı̆̆ını da gösterir:

Maşallah Feride Hanımefendi,

Sen bana altı ay mektup yazma da, sonra ben sana bir iki hafta kağıt göndermemekle sitemlere kalklş!.. İște ben sana hiç mektup göndermeyeceğim; fakat yine senden her posta mektup isteyeceğim. Ne diyeceksin bakayım? Yalan, yalan, iki gözüm kızım! Söylediğime pişman oldum; ben de sana her posta mektup yazarım. Senin de Erkem 'in de, gözlerinizi öperim.

KEMAL (Tansel, 1967. s. 473)

Burada altı aylık bir kopukluk olsa da Kemal, 187 numaralı mektubunda Kıbrıs'a gelen postalar hakkında kızına bilgi verir. Buna göre iki haftada bir Arabistan tarafından bir vapur Kıbrıs'a uğrayıp İstanbul'dan geçer. İstanbul'dan da her Çarşamba Kıbrıs'a bir vapur vardır. İletişim bu sıklıkta olabilir. Bu bilgi mektup trafiğine 1şık tutar. Buna göre kendi yazdığı mektuplar İstanbul'a ulaşmadan kızının mektubu gelmektedir. Kendi mektubu İstanbul'a ulaşmadan merak ettiği hususların, istediği bilgilerin yanıtı gelir.

Namık Kemal'in kızına yazdığı mektupları kısadır. Çoğu 3-7 satırlıktır. En uzunu hitapla birlikte 14 satırdır. Her mektupta gecikme ve aksamadan söz edilerek mektubun önemi vurgulanır. Hemen hemen her mektupta "Ekrem ve Naşid'in gözlerinden öperim" der. Bazı mektuplarında "Validene selam" ve benzeri sözlerle eşine selam gönderir. Bunun nedenini 183 numaralı mektupta açıklar:

Íki Gözüm Feride'ciğim,

Bu haftaki mektubunu aldım; şimdilik bir başka delilik tutturdum: Yalnız kaldıkça muttasıl mektuplarının aynını yazıyorum. Yazarken, seninle konuşmuş kadar ĕ̆leniyorum. Yedi-sekiz gündür rüyama girmiyorsun; sen de mi vefasızlı̆̆a başladın? Inşallah keyifsiz ve sıkıntıda değilsin! Hayır elhamdülillah değilsin.. Eğer hasta veyahut sıkıntıda olsa idin, benim yüreğimde bu kadar emniyet olmak mümkün mi idi. 
Bu mektubumu aldĭ̆ın gibi dŏ̆ru gidersin, benim tarafimdan valide’nin gözlerini öpersin. Kendisine dersin ki, 'Şimdiye kadar mektup veyahut selam gönderemediğim, kă̆ıtlarımın açıldığından ve benim harem lakırdısını kimseye duyurmamak istediğimden idi; bana hatırı kalmasın!

KEMAL (Tansel, 1967. s. 466)

Mektupların hepsinde sağlık ve sıhhat üzerinde durulur. Bazen nezle, iklime bağlı baş ağrısı gibi hastalıklar o hafta mektup yazmalarını engeller. Yine mektuplarda Kemal, kızını rüyasında gördüğünden söz eder. Oğlu Ekrem onun kadar rüyalarına girmez. Mektuplarda sürekli geçen Naşid, Namık Kemal'in Dilber Hanım'dan olan kardeşidir. Ekrem kendisinden iki yaş küçük Naşid için anılarında "Hakiki amcam” demektedir. Namık Kemal, Feride'ye mektuplarında babası ve onun eşi için Beybaba ve Hanımnine diye hitap eder. Rüyalarında göremediği Ekrem'i resimlerde görmek arzusuyla Feride'den onun resmini göndermesini defalarca ister.

Feride Hanım'a,

Ekrem'in bana resmini göndermiyorlar. Git, beybaban ile hanımninen ile kavga et de, mutlak göndersinler. $\mathrm{Bu}$ iş için senden başka güvenecek adamım kalmadı. Bakayım kendine 'Kemal'in kızı' dedirtecek kadar şirretlik edebilir de, çocuğumun bir resmini aldırmă̆a muvaffak olur musun? (Tansel, 1967. s. 466)

Namık Kemal resmin gelmemesini resim çıkartmanın günah olduğuna dair anlayışa bağlar ve "günahtan korkuyor iseniz benim boynuma olsun" dedikten sonra Nuri ile resim gelmezse, bir daha mektup yazmamakla kızı Feride'yi tehdit eder.

Mektuplarda üzerinde en çok durulan hususlardan biri de Feride'nin yazı ve imlasıdır. Namık Kemal zaman zaman onu yüreklendirmek için yazısının düzelip güzelleştiğini, ama imlasında sorunların bulunduğunu söyler:

Hanım Kızım,

Fakat ben İstanbul'dan çıktım çıkalı, daha yazıyı düzeltemedin. Hem Kemal'in kızı olup da, güzel yazı yazmamak sana yakışır mı? Biraz çalışsan ne olur? (Tansel, 1967. s. 470)

İki gözüm Ferideciğim,

Mektubunu aldım. Yazın güzelleşmeğe başlamış; fakat ben yine kanaat etmem! Yazını da senin kadar güzel isterim. Yazın biraz güzelleştikten sonra imlaya çalışcă̆ız. (Tansel, 1967. s. 470)

Namık Kemal uzakta da olsa kızının eğitimiyle, yazısıyla ilgilenir. İmla konusunda dedesinden yardım ve ders almasını öğütler. Yazılarını dedesine tashih ettirerek kendini geliştirebileceğini söyleyip çokça çalışmasını ister. Çok kitap okuması gerektiğini de buna ekler. Yazı konusunda bir mektubu daha alıntılamak isterim:

İki gözüm Ferideciğim,

Sakın geçen hafta sana mektup yazmadı̆̆ıma gücenme! Pek aceleye geldi. Mektubunu almıştım; yazını sormuşsun; düzelmemiş.. Bahusus satırları pek ĕ̆ri gidiyor. Beybabandan çizgili kağıt al da, yazıyı ona yaz! Lakin sözlerin fena değil; gönlündekini yazlyorsun.. Ona pek memnun oluyorum Şu kadar var ki hâk-i pâyiniz gibi siz gibi tabirler kullanıyorsun; imzanı da, cariyeniz diye koyuyorsun. Sen benim cariyem değil, kızımsın; öyle hâk-i pâyiniz gibi tabirler de, yabancı arasında kullanılır. Baba, evlat arasında yapılmaz.. Imzanı Feride koy; lakırdılarını da benim ile konuşur gibi senli benli yaz!..

Validene selam ederim. Ekrem 'in, Naşid'in gözlerini öperim. Mektuplarını ne kadar uzun tutarsan, beni o kadar memnun edersin; senin kağıtların ile her şeyden ziyade ĕgleniyorum...

Baki gözlerini öperim kızım. (Tansel, 1967. s. 476-7)

Bu mektupta önce yazısı üzerinde durur ve nasıl güzelleştireceği yolunda yeni önerilerde bulunur. Ardından üslubuna değinerek gönlündekilerini içtenlikle yazmasını takdirle karşılar. Ancak "hâk-i pâyiniz, siz" gibi hitapların daha resmî mektuplarda kullanılacağını, baba evlat arasında böyle mesafeli hitapların uygun olmadığını söyler. İmza konusundaki söyledikleri de önemlidir. "Cariyeniz değil Feride olarak imza at" diyerek onun öncelikle özgür bir kız, bir birey olduğuna vurgu yapar. Konuşur gibi yazmasını istemesi de onun sade, anlaşılır, akıcı ve halk için yazma düşüncesine uygun bir tutumdur.

Bu mektubun son kısmı da önemlidir. Çünkü Namık Kemal Magosa'da bu mektuplarla avunmakta ve moral bulmaktadır. Ailesiyle ilişkisinin en samimi yansıması bu mektuplardadır. Mektuplardaki hitaplar da bunu göstermektedir. Genellikle "iki gözüm kızım, iki gözüm Ferideciğim” hitabını tercih eden Kemal, biraz gücenik ve sitemli olduğunda "Hanım kızım, hanım kız, maşallah Feride Hanımefendi” gibi mesafeli hitaplar kullanır.

Bir başka noktayı da belirlemek gerekir ki Namık Kemal Magosa'dan babasına dahi mektup yazmamıştır. Ekrem Rüştiyeye başlamasına rağmen henüz ona da mektup göndermez. Mektup yazmak için bir koşul koyar, sınıfında birinci hiç değilse ikinci olursa ona ayrı mektup yazacağı mesajını gönderir. Namık Kemal, gurbette olduğu zaman bile çocuklarının gelişmesini yakından izler. Yaşlarına uygun olan bir biçimde diyalog kurar. Bu onun çocuk ruhundan, gereksinmelerinden haberli olduğunu gösterir. Onlarla çocuklaşmaktan çekinmez. 
Çukurova Üniversitesi Sosyal Bilimler Enstitüsü Dergisi, Cilt 30, Sayı 1, 2021, Sayfa 157-165

\section{SONUÇ}

Namık Kemal, yaşamını Avrupa'da bir tür siyasi kaçak, sürgün, hapis, ikamete memur olması ve resmî görevler nedeniyle İstanbul'dan uzakta geçirmiştir ve son görev yeri olan Sakız Adası'nda vefat etmiştir. Orada defnedilen Namık Kemal'in naaşı, yakın arkadaşı Ebuzziya Tevfik'in bir cins vasiyet kabul ettiği Bolayır'da gömülmek isteğini II. Abdülhamit'e aktarması üzerine Padişahın da onayıyla Süleyman Paşa'nın türbesinin bahçesine nakledilmiştir. Kabrinin tasarımını ise Tevfik Fikret yapmıştır. Ömrünün çoğunu ailesinden, sevdiklerinden, dostlarından ayrı, bitmeyen bir gurbet içinde geçiren Namık kemal iletişimini mektuplarla sağlamıştır. Namık Kemal'in çok sayıda mektup yazdığı bilinmektedir. Çeşitli nedenlerle bu mektupların önemli bir kısmı yok olmuştur. Sayısının birkaç bine ulaştı̆̆ tahmin edilen mektuplardan 1043 tanesi bugüne ulaşmış ve Fevziye Abdullah Tansel tarafindan dört cilt olarak yayımlanmışıtr.

Her bir ciltte Avrupa ve Magosa Mektupları, İstanbul ve Midilli Mektupları I, Midilli Mektupları-II, Rodos ve Sakız Mektupları başlıklarıyla yer alan 1029 mektup bulunmaktadır. Daha sonra bulunan 13 mektup bir ek bölümüyle dördüncü cilde eklenmiştir. Böylelikle elde edilen ve kayıt altına alınan mektup sayısı 1043'e ulaşmıştır. Bundan sonra da bazı mektuplar ortaya çıkabilir. Bu yazıda Namık Kemal'in Magosa mektuplarına yansıyan yaşamı aktarılmıştır.

Namık Kemal'in mektupları ona ilişkin pek çok bilgiyi içermektedir. Mektuplar aracıllı̆ıyla onun, siyasi, edebî yanı, ailevi hayatı ve dostları ile ilişkilerine dair pek çok şeyi öğrenebiliyoruz. Bugün kâğıt üzerine elle mektup yazmak, hatta mektup yazmak neredeyse unutuldu, yerine başka araçlar konuldu; ama o y1llarda en önemli iletişim aracı mektuptu. İyi ki Namık Kemal çok mektup yazmış. Bunların çoğu siyasi nedenlerle yok edilse de kalanlar bize epey malzeme ve bilgi sağlamaktadır. Bunun için kendisine müteşekkiriz. Bu mektupları yayımlayan Fevziye Abdullah Tansel'e de teşekkür borçluyuz. Namık Kemal'in mektuplarını büyük emek sonucu dört cilt halinde yayımladığı için. Bu sayede biz Namık Kemal hakkında ayrıntılı bilgilere ulaşma ve bir kısmını paylaşma olanağına kavuştuk. Mektuplar bunlardan başka pek çok bilgiyi içerdiğinden yeni incelemelere açıktır.

\section{KAYNAKLAR}

Akün, ÖF (1972). Namık Kemal'in Mektubları. No: 1669, İstanbul Üniversitesi Edebiyat Fakültesi Yayınları.

Akün, ÖF (1988). Namık Kemal. İslam Ansiklopedisi, 9, 54-72, Millî Eğitim Basımevi.

Aydoğan, B. (2003). Namık Kemal'in Magosa sürgünlüğü. Çukurova Ü. Sosyal Bilimler Enstitüsü Dergisi, 12, $12,15-28$.

Aydoğan, B. (2010). Namık Kemal'de gerçeğe uygunluk, anlam ve süs ilişkisi. Doğumunun 170. Yllında Uluslararası Namık Kemal Sempozyumu, Tekirdağ.

Kuntay, MC (1956) Nâmık Kemal (Devrinin insanları ve olayları arasinda), II, Maarif Vekaleti.

Tansel, FA (1967). Namık Kemal'in husûsî mektupları C. I. Avrupa ve Magosa Mektupları, Türk Tarih Kurumu Basımevi.

Tansel, FA (1969). Namık Kemal'in husûsî mektupları C.II. İstanbul ve Midilli Mektupları-I, Türk Tarih Kurumu Basımevi.

Tansel, FA (1973). Namık Kemal'in husûsî mektupları C.III. VI. Midilli Mektupları-II, Türk Tarih Kurumu Basımevi.

Tansel, FA (1986). Namık Kemal'in husûsî mektupları C. IV, VII-VIII. Rodos ve Sakız Mektupları, Türk Tarih Kurumu Basımevi. 